\title{
Farklı Yaşam Koşullarında Yaşayan Yaşlıların Mutluluk Düzeyi ve Yaşam Kalitesi: Karşılaştırmalı Bir Çalışma
}

\section{Happiness Level and Life Qualıty of the Elderly Living in Different Life Conditions: A Comparative Study}

\author{
${ }^{1}$ Gul DERTLI, ${ }^{2}$ Mehmet KURCER, ${ }^{3}$ Zeynep ERDOGAN \\ ${ }^{1}$ Community Health Center, Çorum, Turkiye \\ ${ }^{2}$ Zonguldak Bulent Ecevit University, Faculty of Medicine, Public Health Department, Zonguldak, Turkey \\ ${ }^{3}$ Zonguldak Bulent Ecevit University, Ahmet Erdoğan Vocational School of Health Services, Nursing Department, Zonguldak, Turkey
}

Gul Dertli: https://orcid.org/0000-0002-7896-0074

Mehmet Ali Kurcer: https://orcid.org/0000-0003-2672-1079

Zeynep Erdogan: https://orcid.org/0000-0002-7298-7559

\section{ÖZ}

Amaç: Çalışma, farklı yaşam koşullarında yaşayan yaşlıların mutluluk düzeylerini ve yaşam kalitelerini (YK) incelemek amaciyla planlandi.

Materyal ve Metot: Bu araştırma, üç grubun karşılaştırıldığı tanımlayıcı ve kesitsel bir çalışmadır. 1. grup huzurevinde yaşayan $(n=28), 2$. grup aile ortamında yaşayan ancak hastanede tedavi gören $(n=28)$ ve 3 . grup ise aile ortamında yaşayan yaşlılardan $(n=28)$ oluşmuştur. Veriler 6 maddelik sosyo-demografik özellikleri içeren bir anket formu, "Oxford Mutluluk Ölçeği-K1sa Form (OMÖ-KF)" ve Yaşlılar İçin Dünya Sağlik Örgütü Yaşam Kalitesi Modülü (WHOQOL-OLD) Türkçe versiyonu kullanılarak toplanmıştır.

Bulgular: Çalışmaya katılan, aile ortamında yaşayan sağlıklı kadın yaşlıların OMÖ-KF puan ortalamaları, aile ortamı ve huzurevinde yaşayan, erkek yaşlılardan anlamlı derecede yüksektir. Aile ortamında yaşayan, sağlıklı kadın yaşlıların WHOQOL-OLD skorları erkeklere göre anlaml derecede yüksektir. İkiden fazla kronik hastalığı ve psikiyatrik hastalığı olan aile ortamında yaşayan hasta yaşlıların, huzurevinde ve aile ortamında kalan sağlıklı yaşlılara göre WHOQOL-OLD puanları anlamlı düzeyde düşüktür $(\mathrm{p}<0.05)$.

Sonuç: İkiden fazla kronik hastalık veya psikiyatrik hastalığı olan aile ortamında yaşayan yaşlilar, huzurevinde kalan veya aileleriyle yaşayan sağlıklı yaşlılara göre daha az mutlu ve daha düşük yaşam kalitesine sahiptir.

Anahtar Kelimeler: Aile ortamı, huzurevi, mutluluk, sağlıkla ilişkili yaşam kalitesi, yaşlılık

\begin{abstract}
Objective: The study was planned to examine the happiness levels and quality of life (QoL) of the elderly living in different living conditions.

Materials and Methods: This research is a descriptive, cross-sectional study comparing the three groups. The first group consisted of the elderly living in the nursing home $(n=28)$, the second group living in the family environment but treated in the hospital $(\mathrm{N}=28)$ and the third group living in the family environment $(n=28)$.

Results: The mean score of OHS-SF the healthy female elderly who participated in the study and lived in a family environment was significantly higher than the male elderly people living in the family environment and nursing home. The WHOQOL-OLD scores of healthy female elderly people living in a family environment are significantly higher than men. The WHOQOL-OLD scores of the sick elderly who live in a family environment with more than two chronic diseases and psychiatric diseases are significantly lower than the healthy elderly people living in the nursing home and family environment $(\mathrm{p}<0.05)$.
\end{abstract}

Conclusion: Elderly people who have more than two chronic diseases and psychiatric diseases and live in a family environment have less happy and lower QoL compared to those living in other settings.

Keywords: Elderly, family environment, happiness, health-related quality of life, nursing home

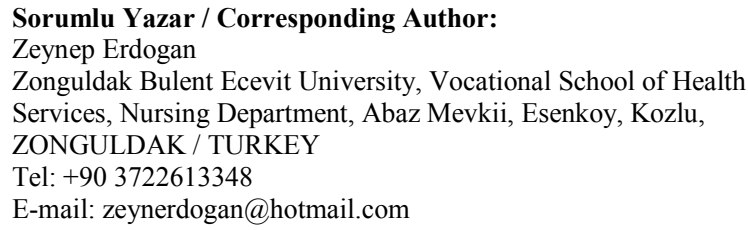

Yayın Bilgisi / Article Info:

Gönderi Tarihi/ Received: 24/05/2020

Kabul Tarihi/ Accepted: 16/11/2020

Online Yayın Tarihi/ Published: 05/03/2021

Atıf / Cited: Dertli G, et al. Happiness Level and Life Quality of the Elderly Living in Different Life Conditions: A Comparative Study. Online Türk Sağllk Bilimleri Dergisi 2021;6(1):53-63. doi: 10.26453/otjhs.742096 


\section{INTRODUCTION}

The World Health Organization (WHO) has named the age of 60 and over as the old age period. Within the elderly population, further classification like oldest old (80+) and centenarian (100+) and even super-centenarian $(110+)$ are also made. Between 2015 and 2050, the proportion of the world's population over 60 years will nearly double from $12 \%$ to $22 \%{ }^{1}$ According to Turkey Statistical Institute (TSI), the elderly population in the general population increased to $8.8 \% .^{2}$ As the elderly population increases, chronic disease morbidity also increases. The need for health services is increasing due to the increase in chronic diseases of nursing homes founded for shelter and psycho-social support. In this context, nursing homes aim to increase the happiness and quality of life (QoL) of the elderly by providing the control of chronic diseases. $^{3}$

Happiness is mostly associated with emotions, feelings or moods and life satisfaction is concerned with people's cognitive evaluations and judgements about their life. ${ }^{3}$ The studies investigating the effects that cause happiness of individuals show that objective approaches cannot fully explain happiness. ${ }^{4}$ Researchers have turned to research subjective structures as some individuals can be happy despite insufficient life conditions and all challenges while others can define themselves as unhappy individuals even in the best situations. ${ }^{5}$ The fact that some individuals can be happy despite all obstacles, lack of love whereas some other individuals are unhappy despite all the advantages and comforts in their lives is related to the subjectivity of happiness. Therefore, the elderly's being happy in their environment is related to their subjective status.

QoL expresses the perceptions of individuals about their positions in life regarding their goals, expectations, standards and concerns in the context of their culture and value systems. ${ }^{6}$ When the studies examining the QoL of the elderly were examined, it was seen that the entity of chronic disease, factors of living in the nursing home or family environment affected the QoL. ${ }^{7,8}$ In spite of the support provided by the medical and social systems to the elderly, many elder individuals still experience unhappiness due to loneliness, depression, social isolation, or decreased QoL. ${ }^{9}$ Therefore, examining happiness has become important for most researchers. Especially in the elderly, both the decreased QoL, the entity of chronic disease and the environment in which the elderly live may affect their level of happiness. This study was carried out to determine the happiness level and QoL of elderly in different life conditions.

\section{MATERIALS AND METHODS}

Before the study, it was approved by the Clinical Research Ethics Committee of Bulent Ecevit University (Date: 10.02.2016, decision no: 2016-3110/02). Each elderly was informed about the study and written consent was obtained from all the elderly.

The aim of study, to examine the happiness level of elderly living in different life conditions and their health-related quality of life. This research is a descriptive cross-sectional study comparing the three groups. The first group consisted of the elderly living in the nursing home, the second group living in the family environment but treated in the hospital and the third group living in the family environment. The research was carried out in a University Faculty of Medicine Hospital and a Nursing Home. The first group of the study consisted of 28 people aged 65 and over in a nursing home who agreed to participate in the study and met the inclusion criteria. The sample size of the first group was based on in forming the second and third groups representing individuals aged 65 and over living with the family. In the second group, 28 people were chosen among 38 people aged 65 and over who stayed at a University Faculty of Medicine Hospital Internal Services and agreed to participate in the study and met the inclusion criteria. In the third group, 28 patients out of 42 were involved in the study who came to visit patients at the age of 65 and over in the a University Faculty of Medicine Hospital Internal Services, agreed to participate in the study and met the inclusion criteria. While collecting data, "Socio-demographic Information Form" consisting of 6 questions including sociodemographic features (age, gender, marital status, educational status), entity of chronic disease, the situation of seeing their children, and "Oxford Happiness Scale (OHS-SF)" to determine the happiness level, Turkish version of the Quality of Life Scale Elderly Module (WHOQOL-OLD.TR) to determine the quality of life of individuals were used. The Turkish version of the scale, developed by Hills and Argyle, ${ }^{14}$ consists of 8 questions with a 5point Likert type scale an done dimension was made by Doğan and Çötok. ${ }^{10,11}$ High scores indicate that 
the level of happiness is high Doğan and Çötok found that Cronbach's alpha value is $0.91 .^{11}$ The WHOQOL-OLD module, specialized for the elderly and developed by the World Health Organization, consists of 24 questions in six dimensions, in which the answers are determined by a five-point Likert scale. ${ }^{12}$ These six dimensions are included under the heading of "sensory functions", "autonomy", "past, present and future activities", "social participation", "dying and death", "intimacy". As the score increases, the quality of life improves. The validity and reliability of study of Turkish WHOQOL-OLD was performed by Eser et al. The Chronbach Alpha value is 0.85 . WHOQOL-OLD consists of six dimensions and a maximum of 120 points can be obtained. ${ }^{13}$ Elderly people aged 64 and under, diagnosed with cancer, having Alzheimer's and dementia, non-sane and not volunteers were excluded from the study. The data obtained from the study were evaluated in the statistical package for the social sciences (SPSS) 18 program. Descriptive statistics, one-way analysis of variance (ANOVA) and t-test in independent groups were used to evaluate the data. $\mathrm{p}<0.05$ was considered statistically significant.

\section{RESULTS}

The distributions of socio-demographic features and some variables of the elderly participated in this research according to their environment are given in Table 1. According to Table 1; approximately half of the elderly who are living in the family environment in the first group are between the ages of 65-74 and 75-84. It is mostly male (78.6\%), about half of them are primary school graduates $(42.9 \%)$, married $(64.3 \%)$, have children $(96.4 \%)$, and all of them see their children. The most of the elderly have more than 2 chronic diseases, the most common diseases are DM (40.7\%), HT (39.3\%) and COPD (39.3\%), respectively. Approximately half of the healthy elderly individuals living in the family environment (46.4\%) are between the ages of 65-74 and 75-84. Similarly, most of them are male (78.6\%), primary school graduates $(35.7 \%)$, about half are married (53.6), the majority have children $(85.7 \%)$ and all of them see their children. Nearly half of them (43.2\%) have a chronic disease. The most common ones are DM (40.7\%) and HT $(42.9 \%)$, respectively. Almost half of the elderly $(42.9 \%)$ staying in nursing homes are in the $65-74$ age range. Similarly, the majority are male $(78.6 \%)$, about half are primary school graduates $(53.5 \%)$, and unlike the other 2 groups, they are mostly single $(92.9 \%)$. The majority of them do not have children $(60.7 \%)$. The majority of those who have children (71.4\%) see them. When the available chronic disease numbers are analyzed, those with a disease $(32.1 \%)$ and those with two diseases $(32.1 \%)$ are at a similar rate.

The comparison of total and sub-dimension scores of WHOQOL-OLD Scale and OHS-SF according to the environment in which the elderly live is given in Table 2. While there was no significant difference between the groups in terms of WHOQOL-OLD sub -dimensions of sensory functions, autonomy, pastpresent-future activities, social participation, intimacy and WHOQOL-OLD total score and OHSSF scores of patients and healthy elderly living in the nursing home and family environment participating in the study $(\mathrm{p}>0.05)$, there was a significant difference in terms of dying and death sub-dimensions $(p=0.03)$.

The distribution of OHS-SF scores according to socio-demographic features of the elderly is given in Table 3. The mean score of OHS-SF of healthy female elderly living in the family environment participating in the study is significantly higher than male $(p<0.001)$. There is no significant difference between the other two groups in terms of OHS-SF scores by gender. In addition, while there is no significant difference between the elderly groups in terms of marital status, education level, state of seeing the children, availability of DM and HT and the scores of OHS-SF ( $>>0.05$ ); the mean scores of OHS-SF of the sick elderly who live with their families, have more than two chronic diseases $(p<0.05)$ and a psychiatric illness $(p<0.05), C R F$ $(p<0.001)$, COPD $(p<0.05)$ are significantly lower than the healthy elderly living in the nursing home and family environment.

The distributions of WHOQOL-OLD scores of the elderly according to their socio-demographic features and some variables are given in Table 4. According to Table 4, WHOQOL-OLD scores of healthy females living in the family environment were significantly higher than males $(p<0.001)$. No significant differences were found in the three groups in terms of age, marital status, education, state of seeing children, chronic diseases such as Diabetes mellitus (DM), hypertension (HT), chronic renal failure $(\mathrm{CRF})$, Chronic obstructive pulmonary disease (COPD) $(p>0.05)$ and WHOQOL-OLD scores. However, the WHOQOL-OLD scores of sick elderly people living with their families, having 
more than two chronic diseases and a psychiatric illness were significantly lower than the healthy elderly people living in a nursing home and family environment $(\mathrm{p}<0.05)$.

However, the WHOQOL-OLD scores of sick elderly people living with their families, having more than two chronic diseases and a psychiatric illness were significantly lower than the healthy elderly people living in a nursing home and family environment $(\mathrm{p}<0.05)$.

\section{DISCUSSION AND CONCLUSION}

Issues such as the relationship of disease and death with care, which groups among the elderly need care in different periods, the reasons for being taken care of at the nursing home, how long they will stay in care have been investigated throughout the industrial age. ${ }^{14}$ In this study, the effect of the chronic disease entity, which has not been adequately questioned until today, on the happiness and quality of life in health of the healthy or sick elderly people living in a nursing home or family environment was investigated. Staying in a nursing home or family environment and being sick or healthy await every individual in the last period of life like a spiral that changes in time. Happiness is a virtue in the form of acceptance, approval, self-worth, respect, developing warm and supportive relationships with the environment, increasing life fulfillment with joy, satisfaction or welfare, providing an advantageous environment. ${ }^{4,15}$ Although there is an agreement that happiness affects individuals positively, there is no unity in what it is and how happy individuals are since individuals' perspectives on happiness change due to the environment they live in. ${ }^{5}$

In this study, there is no significant difference between the sick elderly living in the family environment, the healthy elderly living in the family environment and the elderly living in a nursing home in terms of mean OHS-SF scores. When we examined the distribution of OHS-SF scores according to the socio-demographic features of the elderly, OHS-SF mean score of healthy women living in a family environment was significantly higher than that of men. There was no significant difference between the elderly living in the other 2 groups in terms of OHS-SF scores by gender. In the studies Neocleous et al. conducted in Southern Cyprus $^{16}$ and Azami et al. in Tehran ${ }^{17}$ they measured the happiness levels of the elderly living in their own homes and nursing homes and found out that the elderly living in their own homes were significantly happier than those living in nursing homes. Özer et al. also reported that women living in a family environment had a better life satisfaction than women and men in a nursing home. ${ }^{18}$ In this study, it was seen that healthy women staying in the family environment were happier than men, but the happiness levels among men and women staying in the hospital and nursing home were similarly at a low level. On the other hand, while Neocleous and Azami reported that elderly people were happier at home than nursing home without showing any gender discrepancy, the distinction of this study was that only healthy women were happy at home, and male elderly people obtained low levels of happiness without any significant differences between them in home, nursing home or hospital environment. ${ }^{16,17}$ Dale et al. reported in the study in which they examined the factors affecting survival in nursing homes that male gender was determinant in mortality. ${ }^{19}$ For this reason, it can be said that the unhappiness of elderly men is low regardless of residence conditions and is an issue that should be examined thoroughly. In this study, age, marital status, education, or seeing children did not affect happiness. Moeini et al. and Akyıl et al. did not find any differences between the elderly according to their marital status similarly to our study results. ${ }^{8,20}$ In this study, OHS-SF mean score of the patients with more than two chronic diseases, living in a family environment with $\mathrm{CRF}$, COPD and psychiatric illness was found significantly lower than those of healthy elderly people living in a nursing home and family environment. The aging process is often accompanied by comorbidity and is an important determinant of health outcomes in elder adults. Comorbidity is responsible for a high treatment burden, increased hospitalization and death risk. In the final report of disease burden carried out in Turkey in 2000, it was determined that chronic diseases were the most common reason for death in men and women aged 60 and over. ${ }^{21,22}$ Ischemic heart disease, which leads to loss of function in the elderly and causes a decrease in system functions in this period, cerebrovascular diseases, chronic obstructive pulmonary disease, diabetes, alzheimer, dementia and osteoarthritis are among the first 10 diseases and cause loss of years in life. ${ }^{23}$ A striking point in this study was that elderly people staying at a nursing home had a significantly lower rate of chronic diseases than healthy and sick elderly people in the family environment. Although that seemed to be a positive 
situation at first glance, it was reported that elderly people with comorbidity in nursing homes had a higher mortality rate than that of society. Dale et al. reported survival as 5.9 years after admission to the nursing home in his study in which he examined the factors affecting survival in nursing homes. ${ }^{19}$ Vossius et al. found the survival rate as 2.2 years in their longitidunal study that they observed the mortality of elderly people he followed for 3 years in 690 nursing homes and ascertained that the third of the elderly decreased each year. ${ }^{19,24}$ Dale, et al. and Vossius et al. reported that comorbidity, respiratory system diseases and dementia were determinant in mortality. In this study, it was found that sick elderly living in the family environment and had comorbidity, COPD and psychiatric diseases were more miserable. ${ }^{19,24}$

Since the aging process is associated with chronic diseases, increased disability and more dependence on others, decreases in quality of life are observed with prolonged life span. ${ }^{7}$ Considering the studies examining the quality of life of the elderly, it was seen that the entity of chronic disease, factors related to living in a nursing home or family environment affected the quality of life.

In this study, when the WHOQOL-OLD scores of the elderly were examined according to sociodemographic features and some variables, healthy women living in the family environment had a better quality of life than men, and there was no significant difference between the WHOQOL-OLD scores and the three groups in terms of other features such as age, marital status, education, seeing children and chronic diseases like DM, HT, CRF and COPD. However, the quality of life of the elderly people living in the family environment with more than two chronic diseases and psychiatric illness was found to be low compared to the healthy elderly living in the nursing home and family environment. However, the quality of life of the elderly people living in the family environment with more than two chronic diseases and psychiatric illness was found to be low compared to the healthy elderly living in the nursing home and family environment.

Karakaya et al. found the QoL levels of the elderly living in the nursing home lower than those living at home in the study they carried out in Muğla. ${ }^{25}$ Additionally, age, marital status, education level, and seeing children did not affect the quality of life in health. Only women living in the family environment had a higher quality of life than men.
However, the quality of life of the elderly staying in the nursing home and in the hospital did not change according to gender. ${ }^{26}$ While the quality of life scores of women were found high in the family environment, being in a nursing home, homestay or hospital equally reduced the quality of life of men. The aging process in men seems to be a problem in itself regardless of the environment.

In this study, while the quality of life scores of the elderly in the family environment with more than three chronic diseases and psychiatric illness were significantly lower than the healthy elderly in the nursing home and family environment, there was no difference between the elderly with DM, HT, CRF, COPD and those without them in terms of QoL. Similar to this study, Brown et al. found that while there was no difference between the quality of life of the elderly people with CRF and without CRF, the quality of life was significantly lower in those with psychiatric problems. ${ }^{26}$ Carreiro-Martins et al. found that elderly people with COPD in 53 nursing homes in Portugal had a significantly lower quality of life compared to the elderly without COPD. ${ }^{27}$ Compatible with this study, Onunkwor et al. showed that multiple comorbidities significantly decreased the quality of life of the elderly living in a nursing home in Kuala Lumpur. ${ }^{28}$

In their study in Ankara, Erkal et al. found a significant difference between the QoL of those who were married, high-educated, had a high-income and other groups. ${ }^{21}$ The study on the elderly conducted by Yagcioglu in Konya province supported this study by not having a significant relationship between the quality of life according to marital status. $^{23}$ The results of these studies indicate that marriage itself is not a fact that may bring happiness. Due to this study's especially being conducted in elderly groups, the loss of the meaning of marriage in youth, the entity of chronic diseases, the undertaking of care by one person, the living environments such as nursing home and other problems related to aging may prevent happiness that is expected from marriage.

In this study, it is possible to interpret that the socialization given by the nursing home relieves the death anxiety as the mean scores of Dying and Death sub-dimensions of WHOQOL-OLD Scale were found to be lower in the elderly in nursing homes than the healthy and sick elderly living in the family environment and people staying in the nursing home experienced less worry, anxiety and 
fears about death. Altay et al. found the anxiety of death in the elderly staying in the nursing home low in those who perceived it as a part of life. The lower level of death anxiety of the nursing home residents in this study may indicate that they can view life more positively. ${ }^{29}$ In this study, it was determined that OHS-SF and WHOQOL-OLD scale scores were not affected by the status of the elderly's seeing their children. In the study conducted by Şahin and Emiroğlu, when the status of having children and quality of life scores of the elderly were examined, there was no relationship between those having and not having children. ${ }^{7}$ This may emphasize the importance of what kind of a life is maintained by them rather than seeing their children.

In this study, the OHS-SF and WHOQOL-OLD scores of healthy women living in the family environment were found to be high. Living in a nursing home or family environment does not affect happiness and quality of life in health, except for the death sub-dimension. It can be said that the elderly staying in the nursing home have less negative perceptions about death than the elderly living in the family environment. This may suggest that the nursing home does not seek the family environment, but rather has a function to reduce anxiety of death. It shows that families can leave their close relatives to the nursing home readily when they have difficulty. In addition, it was determined that elderly patients hospitalized with more than two chronic diseases or psychiatric illness were less happy and had a lower quality of life than healthy elderly people staying in the nursing home or living with their families. It was even found that having only COPD, CRF and psychiatric illness negatively affected the happiness scores of elderly patients hospitalized, and having just psychiatric illness negatively affected the quality of life. Therefore, having a male gender and the entity of chronic disease negatively affect the happiness and quality of life regardless of the environment in which the elderly live. These groups can be chosen as strategic targets for the interventions to be performed. Due to the difficulty of reaching the elderly living in their homes, it was accepted that the elderly who stayed in the hospital and came to visit the patients represented the elderly living in the family environment.

Ethics Committee Approval: Our study was approved by the Clinical Research Ethics
Committee of Bulent Ecevit University (Date: 10.02.2016, decision no: 2016-31-10/02).

Conflict of Interest: No conflict of interest was declared by the authors.

Author Contributions: Concept - GD, MAK; Supervision - GD, MAK, ZE; Materials - GD, MAK, ZE; Data Collection and/or Processing - GD, MAK; Analysis and/or Interpretation - GD, MAK, ZE; Writing - MAK, ZE.

Peer-review: Externally peer-reviewed.

\section{REFERENCES}

1. World Health Organization. Elderly Population. http://origin.searo.who.int/entity/ health_situation_trends/data/chi/elderlypopulation/en/2020. Accessed October 14, 2020.

2. Turkish Statistical Institute. https:// hsgm.saglik.gov.tr/depo/birimler/kronikhastaliklarengellidb/hastaliklar/Yasli_Sagligi/ $\mathrm{r}$ a p o r l a r_ i s t a t i s t i k l e r/ TUIK_Yasli_Istatistik_2018.pdf. Accessed 01, May 2020.

3. Artan T, Irmak HS. Evaluation of the perspective of aging in nursing home of elderly living in nursing homes: Sample of Istanbul Bahçelievler, Zeytinburnu and Sultangazi nursing home. Society and Social Work. 2018;29(2):51-70.

4. Ngamaba KH, Soni D. Are happiness and life satisfaction different across religious groups? Exploring determinants of happiness and life satisfaction. J Relig Health. 2018;57:2118-2139.

5. Akın HB, Şentürk E. Analysing levels of happiness of individuals with ordinal logistic analysis. Oneri Journal. 2012;10(37):183-193.

6. Bowling A. Enhancing later life: How older people perceive ageing? Aging Ment Health. 2008;12(3):293-301.

7. Ercan Şahin N, Emiroğlu O. Quality of life and related factors of older people in nursing home. Journal of Hacettepe University Faculty of Nursing. 2014;1(1):57-66.

8. Akyıl Çevik R, Adıbelli D, Erdem N, Kırăg N, Aktaş B, Karadakovan A. The relationship between loneliness and perceived social support and happiness levels in the nursing home and the elderly who stay at home. Anadolu Nursing and Health Sciences Journal. 2018;21(1):33-41.

9. Diener E, Scollon CN, Lucas RE. The evolving concept of subjective well-being: The multifaceted nature of happiness. Advances in Cell Aging 
and Gerontology. 2009;15:187-19. doi:10.1016/ S1566-3124(03)15003-1

10. Hills P. Argyle M. The Oxford happiness questionnaire: A compact scale for the measurement of psychological well-being. Personality and Individual Differences. 2002;33(7):1073-1082.

11. Doğan T, Çötok NA. Adaptation of the short form of the oxford happiness questionnaire into turkish: a validity and reliability study. Turkish Psychological Counseling and Guidance Journal. 2011;4(36):165-170.

12. Power M, Quinn K, Schmidt S. Development of the WHOQOL-OLD module. Qual Life Res. 2005;14(10):2197-2214.

13. Eser S, Saatli G, Eser E, Baydur H, Fidaner, C. The reliability and validity of the Turkish version of the World Health Organization Quality of Life Instrument-Older Adults Module (WHOQOLOld). Turk Psikiyatri Derg. 2010;21(1):37-48.

14. Burcu E, Akalın E. Sociological discussions on the case of death. HÜTAD. 2008;8:29-54.

15. Akın A, Satıcı SA. Subjectıve happiness scale: a study of validity and reliability. Sakarya University Journal of Education Faculty. 2011;21 (21):65-78

16. Neocleous G, Apostolou. Happiness in and out of nursing homes: The case of Cyprus. International Social Work. 2016;59(4):533-544.

17. Azami E, Sadeghi Z, Ravandi S. A comparative investigation of mental health and happiness among elderly living at home and nursing home residents Journal of Geriatric Nursing. 2016;3 (1):76-88.

18. Özer M, Karabulut ÖÖ. Satisfaction of life in elderly individuals. Turk J Geriatrics. 2003;6:7274.

19. Dale MC, Burns A, Panter L, Morris J. Factors affectıng survival of elderly nursing home residents. Int J Geriatr Psychiatry. 2001;16(1):70-76.

20. Moeini B, Barati M, Farhadian M, Ara MH. The association between social support and happiness among elderly in Iran. Korean J Fam Med. 2018;39(4):260-265.

21. Erkal S, Şahin H, Sürgit EB. Examination of the relationship between the quality of life and demographic and accident-related characteristics of elderly people living in a nursing home. Turkish Journal of Geriatrics. 2011;14(1):5-53.

22. De Souto, Barreto P, Lapeyre-Mestre M, Vellas B, Rolland Y. Multimorbidity type, hospitalizations and emergency department visits among nursing home residents: a preliminary study. J Nutr Health Aging. 2014;18(7):705-709. doi:10. 1007/s12603-014-0030-6

23. Yağcioğlu R. Examination of the factors affecting the quality of life of elderly people over 65 in nursing homes. Department of Social Work. Institute of Health Sciences Master's Thesis, Konya, Turkey. 2013.

24. Vossius C, Selbæk G, Šaltytė Benth J, Bergh S. Mortality in nursing home residents: A longitudinal study over three years. PLoS One. 2018;13(9): e0203480. doi:10.1371/journal. pone.0203480.

25. Karakaya MG, Bilgin SC, Ekici G, Köse N, Otman AS. Functional mobility, depressive symptoms, level of independence. and quality of life of the elderly living at home and in the nursing home. J Am Med Dir Assoc. 2009;10(9):662666. doi:10.1016/j.jamda.2009.06.002

26. Brown MA, Collett GK, Josland EA, Foote C, Li Q, Brennan FP. CKD in elderly patients managed without dialysis: Survival, symptoms, and quality of life. Clin J Am Soc Nephrol. 2015;10 (2):260-268.

27. Carreiro-Martins P, Gomes-Belo J, Papoila AL, et al. Chronic respiratory diseases and quality of life in elderly nursing home residents. Chron Respir Dis. 2016;13(3):211-219. doi:10.1177/ 1479972316636990

28. Onunkwor OF, Al-Dubai SAR, George PP, et al. A cross-sectional study on quality of life among the elderly in non-governmental organizations' elderly homes in Kuala Lumpur. Health Qual Life Outcomes. 2016;14(6):1-10. doi:10.1186/ s12955-016-0408-8

29. Altay B, Çavuşoğlu F, Çal A. The factors affecting the perception of elderly patients towards health quality of life. TAF Prev Med Bull. 2016;15(3):181-89. 
Table 1. The distribution of socio-demographic and some features of the elderly according to their environment $(\mathrm{n}=84)$.

\begin{tabular}{|c|c|c|c|c|c|c|c|}
\hline \multicolumn{2}{|c|}{ Socio-demographic and Some Variables } & \multicolumn{2}{|c|}{$\begin{array}{c}\text { Family } \\
\text { Environment } \\
\text { (Sick) } \\
\text { n=28 \% }\end{array}$} & \multicolumn{2}{|c|}{$\begin{array}{c}\text { Family } \\
\text { Environment } \\
\text { (Healthy) } \\
\text { n=28\% }\end{array}$} & \multicolumn{2}{|c|}{$\begin{array}{c}\begin{array}{c}\text { Nursing } \\
\text { Home }\end{array} \\
\text { n=28\% }\end{array}$} \\
\hline \multirow[t]{2}{*}{ Age } & $65-74$ & 13 & 46.4 & 13 & 46.4 & 9 & 42.9 \\
\hline & $75-85$ and over & 15 & 53.6 & 15 & 63.6 & 19 & 57.1 \\
\hline \multirow[t]{2}{*}{ Gender } & Female & 6 & 33.3 & 6 & 33.3 & 6 & 33.3 \\
\hline & Male & 22 & 78.6 & 22 & 78.6 & 22 & 78.6 \\
\hline \multirow{4}{*}{$\begin{array}{l}\text { Educational } \\
\text { Background }\end{array}$} & Illiterate & 10 & 35.7 & 6 & 21.4 & 5 & 17.9 \\
\hline & Primary & 12 & 42.9 & 10 & 35.7 & 15 & 53.5 \\
\hline & Secondary & 3 & 10.7 & 3 & 10.7 & 4 & 14.3 \\
\hline & HighSchool University & 3 & 10.7 & 9 & 32.2 & 4 & 14.3 \\
\hline \multirow[t]{2}{*}{ Marital Status } & Married & 18 & 64.3 & 15 & 53.6 & 2 & 7.1 \\
\hline & Single & 10 & 35.7 & 13 & 46.4 & 26 & 92.9 \\
\hline \multirow[t]{2}{*}{ The state of children } & Yes & 27 & 96.4 & 24 & 85.7 & 11 & 39.3 \\
\hline & No & 1 & 3.6 & 4 & 14.3 & 17 & 60.7 \\
\hline \multirow{2}{*}{$\begin{array}{l}\text { The state of seeing } \\
\text { children }\end{array}$} & Yes & 28 & 100.0 & 28 & 100.0 & 20 & 71.4 \\
\hline & No & 0 & 0.0 & 0 & 0.0 & 8 & 28.6 \\
\hline \multirow[t]{3}{*}{ Chronic Diseases } & No & 2 & 7.1 & 5 & 29.5 & 10 & 35.8 \\
\hline & Yes(only one) & 12 & 32.1 & 16 & 43.2 & 9 & 32.1 \\
\hline & Yes(2 and over) & 14 & 60.8 & 7 & 33.3 & 9 & 32.1 \\
\hline \multirow[t]{2}{*}{ DM } & Yes & 11 & 40.7 & 11 & 40.7 & 5 & 18.5 \\
\hline & No & 17 & 60.7 & 17 & 60.7 & 23 & 82.1 \\
\hline \multirow[t]{2}{*}{ CRF } & Yes & 2 & 7.1 & 0 & 0.0 & 3 & 10.7 \\
\hline & No & 26 & 92.9 & 28 & 100.0 & 25 & 89.3 \\
\hline \multirow[t]{2}{*}{ HT } & Yes & 11 & 39.3 & 12 & 42.9 & 10 & 35.7 \\
\hline & No & 17 & 60.7 & 16 & 57.1 & 18 & 64.3 \\
\hline \multirow[t]{2}{*}{ COPD } & Yes & 11 & 39.3 & 3 & 10.7 & 0 & 0.0 \\
\hline & No & 17 & 60.7 & 25 & 89.3 & 28 & 100.0 \\
\hline \multirow[t]{2}{*}{ Psychiatric Illness } & Yes & 4 & 14.3 & 3 & 10.7 & 6 & 21.4 \\
\hline & No & 24 & 85.7 & 25 & 89.3 & 22 & 78.6 \\
\hline
\end{tabular}


Table 2. The Comparison of total and sub-dimensions scores of WHOQOL-OLD scale and OHS-SF according to elderly groups $(\mathrm{n}=84)$.

\begin{tabular}{|l|l|l|l|l|l|}
\hline & \multicolumn{1}{|c|}{$\begin{array}{c}\text { Family } \\
\text { Environment } \\
\text { (Sick) } \\
\text { Mean } \pm \text { SD } \\
(\mathbf{n}=\mathbf{2 8})\end{array}$} & $\begin{array}{c}\text { Family } \\
\text { Environment } \\
\mathbf{( H e a l t h y )} \\
\text { Mean } \pm \text { SD } \\
(\mathbf{n = 2 8 )}\end{array}$ & $\begin{array}{c}\text { Nursing Home } \\
\text { Mean } \pm \text { SD } \\
(\mathbf{n = 2 8})\end{array}$ & $\begin{array}{c}\text { Total } \\
\text { Mean } \pm \text { SD }\end{array}$ & *p \\
\hline OHS-SF & $121.4 \pm 25.29$ & $129.0 \pm 21.95$ & $128.3 \pm 20.48$ & $126.2 \pm 22.66$ & 0.383 \\
\hline $\begin{array}{l}\text { Sensory } \\
\text { Functions }\end{array}$ & $8.3 \pm 2.69$ & $7.5 \pm 1.45$ & $8.1 \pm 1.78$ & $7.8 \pm 1.65$ & 0.394 \\
\hline Autonomy & $16.0 \pm 3.20$ & $15.8 \pm 2.44$ & $17.1 \pm 3.10$ & $16.3 \pm 2.95$ & 0.241 \\
\hline $\begin{array}{l}\text { Past-Today- } \\
\text { Future Activities }\end{array}$ & $14.6 \pm 2.94$ & $13.8 \pm 2.65$ & $14.3 \pm 4.02$ & $14.3 \pm 3.24$ & 0.665 \\
\hline $\begin{array}{l}\text { Social } \\
\text { Participation }\end{array}$ & $12.6 \pm 3.71$ & $13.2 \pm 2.87$ & $13.3 \pm 3.83$ & $13.0 \pm 3.47$ & 0.763 \\
\hline Dying and Death & $\mathbf{1 3 . 3} \pm \mathbf{5 . 0 3}$ & $12.8 \pm 3.98$ & $10.7 \pm 5.05$ & $12.3 \pm 4.79$ & $\mathbf{0 . 0 3 6 *}$ \\
\hline Intimacy & $15.0 \pm 3.63$ & $14.8 \pm 3.08$ & $14.1 \pm 4.03$ & $14.6 \pm 3.57$ & 0.678 \\
\hline $\begin{array}{l}\text { WHOQOL-OLD } \\
\text { Total Score }\end{array}$ & $78.3 \pm 10.96$ & $78.0 \pm 10.83$ & $77.9 \pm 13.51$ & $78.6 \pm 11.82$ & 0.737 \\
\hline
\end{tabular}

*:p $<0.05 ;$ ANOVA test 
Table 3. The distribution of OHS-SF scores of elderly according to their socio-demographic features $(\mathrm{n}=84)$.

\begin{tabular}{|c|c|c|c|c|c|}
\hline \multirow{2}{*}{\multicolumn{2}{|c|}{$\begin{array}{l}\text { Socio-Demographic Features and } \\
\text { Some Variables }\end{array}$}} & \multicolumn{3}{|c|}{ OHS-SF Mean Score } & \multirow[b]{2}{*}{$\mathbf{p}$} \\
\hline & & $\begin{array}{c}\text { Family } \\
\text { Environment } \\
\text { (Sick) } \\
\text { Mean } \pm \text { SD }\end{array}$ & $\begin{array}{c}\text { Family } \\
\text { Environment } \\
\text { (Healthy) } \\
\text { Mean } \pm \text { SD }\end{array}$ & $\begin{array}{c}\text { Nursing } \\
\text { Home } \\
\text { Mean } \pm \text { SD }\end{array}$ & \\
\hline \multirow[b]{2}{*}{ Gender } & Female & $115.3 \pm 27.50$ & $150.3 \pm 16.48 * *$ & $126.8 \pm 13.48$ & 0.001 \\
\hline & Male & $123.0 \pm 15.29$ & $123.0 \pm 15.29$ & $128.7 \pm 15.29$ & 0.780 \\
\hline \multirow{2}{*}{ Age } & 74 and below & $123.2 \pm 14.38$ & $133.4 \pm 16.42$ & $135.0 \pm 13.57$ & 0.343 \\
\hline & 75 and over & $119.6 \pm 13.28$ & $127.6 \pm 12.76$ & $125.0 \pm 14.35$ & 0.757 \\
\hline \multirow{2}{*}{$\begin{array}{l}\text { Marital } \\
\text { Status }\end{array}$} & Married & $120.5 \pm 23.08$ & $133.5 \pm 14.61$ & $117.0 \pm 14.25$ & 0.540 \\
\hline & Single & $122.2 \pm 29.52$ & $124.2 \pm 22.19$ & $129.1 \pm 15.19$ & 0.760 \\
\hline \multirow[t]{3}{*}{ Education } & Illitirate & $111.0 \pm 11.70$ & $126.8 \pm 11.70$ & $122 \pm 15.60$ & 0.346 \\
\hline & Primary School & $114.5 \pm 16.77$ & $124.5 \pm 16.77$ & $138.3 \pm 15.68$ & 0.564 \\
\hline & $\begin{array}{l}\text { High School } \\
\text { University }\end{array}$ & $124.6 \pm 21.29$ & $132.6 \pm 21.29$ & $131.2 \pm 15.17$ & 0.345 \\
\hline \multirow{2}{*}{$\begin{array}{l}\text { The state of } \\
\text { seeing children }\end{array}$} & Yes & $120.5 \pm 23.84$ & $133.3 \pm 14.99$ & $121.0 \pm 18.18$ & 0.639 \\
\hline & No & $130.0 \pm 29.00$ & $130.4 \pm 14.91$ & $128.8 \pm 19.75$ & 0.710 \\
\hline \multirow{2}{*}{$\begin{array}{l}\text { Chronic } \\
\text { Diseases }\end{array}$} & Two and more & $112.7 \pm 23.76^{*}$ & $124.2 \pm 22.76$ & $124.0 \pm 16.48$ & 0.038 \\
\hline & No & $130.0 \pm 22.01$ & $130.8 \pm 22.01$ & $130.9 \pm 15.29$ & 0.574 \\
\hline \multirow{2}{*}{ DM } & Yes & $120.6 \pm 19.85$ & $124.6 \pm 21.62$ & $129.0 \pm 22.53$ & 0.126 \\
\hline & No & $123.2 \pm 26.25$ & $132.2 \pm 22.66$ & $124.0 \pm 4.49$ & 0.362 \\
\hline \multirow{2}{*}{ CRF } & Yes & $87.5 \pm 22.90 * *$ & $127.3 \pm 21.18$ & $128 \pm 21.33$ & 0.001 \\
\hline & No & $124.6 \pm 19.90$ & $129.6 \pm 22.90$ & $130.3 \pm 14.00$ & 0.961 \\
\hline \multirow{2}{*}{ HT } & Yes & $116.0 \pm 15.29$ & $125.5 \pm 23.61$ & $127.8 \pm 22.01$ & 0.637 \\
\hline & No & $121.0 \pm 14.38$ & $121.5 \pm 20.05$ & $128.7 \pm 13.57$ & 0.352 \\
\hline \multirow{2}{*}{ COPD } & Yes & $109.2 \pm 29.55 *$ & $128.2 \pm 29.55$ & - & 0.022 \\
\hline & No & $129.0 \pm 19.81$ & $135.5 \pm 20.88$ & $128.3 \pm 20.48$ & 0.591 \\
\hline \multirow[b]{2}{*}{$\begin{array}{l}\text { Psychiatric } \\
\text { Illness }\end{array}$} & Yes & $94.7 \pm 34.12 *$ & $127.9 \pm 34.12$ & $126.0 \pm 14.23$ & 0.043 \\
\hline & No & $125.8 \pm 21.89$ & $138.3 \pm 21.89$ & $128.9 \pm 10.51$ & 0.632 \\
\hline
\end{tabular}

$*: \mathrm{p}<0.05 ; * *: \mathrm{p}<0.001 ;$ ANOVA test. 
Table 4. The distribution of WHOQOL-OLD scores of the elderly according to their socio-demographic features and some variables.

\begin{tabular}{|c|c|c|c|c|c|}
\hline \multirow{2}{*}{$\begin{array}{c}\text { Socio- } \\
\text { Demographic } \\
\text { Features and } \\
\text { Some } \\
\text { Variables }\end{array}$} & \multirow[b]{2}{*}{ Status } & \multicolumn{4}{|c|}{ WHOQOL-OLD Scores } \\
\hline & & $\begin{array}{c}\text { Family } \\
\text { Environment } \\
\text { (Sick) } \\
\text { Mean } \pm \text { SD }\end{array}$ & $\begin{array}{c}\text { Family } \\
\text { Environment } \\
\text { (Healthy) } \\
\text { Mean } \pm \text { SD }\end{array}$ & $\begin{array}{c}\text { Nursing } \\
\text { Home } \\
\text { Mean } \pm \text { SD }\end{array}$ & $\mathbf{p}$ \\
\hline \multirow[b]{2}{*}{ Gender } & Female & $81.6 \pm 25.08$ & $87.0 \pm 10.08 * *$ & $83.5 \pm 7.17$ & 0.001 \\
\hline & Male & $74.6 \pm 27.50$ & $75.6 \pm 10.79$ & $76.0 \pm 14.23$ & 0.553 \\
\hline \multirow[t]{2}{*}{ Age } & 74 and below & $83.1 \pm 9.56$ & $76.1 \pm 10.08$ & $81.5 \pm 10.43$ & 0.128 \\
\hline & 75 and over & $77.1 \pm 10.78$ & $79.1 \pm 11.90$ & $76.1 \pm 11.51$ & 0.674 \\
\hline \multirow{2}{*}{$\begin{array}{l}\text { Marital } \\
\text { Status }\end{array}$} & Married & $80.8 \pm 9.94$ & $80.8 \pm 10.49$ & $75.5 \pm 7.17$ & 0.588 \\
\hline & Single & $78.9 \pm 14.07$ & $75.6 \pm 14.23$ & $78.0 \pm 14.23$ & 0.236 \\
\hline \multirow[t]{3}{*}{ Education } & Illitirate & $75 . \pm 15.17$ & $83.0 \pm 6.00$ & $74.0 \pm 2.75$ & 0.851 \\
\hline & $\begin{array}{l}\text { Primary } \\
\text { School }\end{array}$ & $83.5 \pm 8.24$ & $78.6 \pm 10.60$ & $83.5 \pm 3.73$ & 0.671 \\
\hline & $\begin{array}{l}\text { HighSchool } \\
\text { University }\end{array}$ & $72.6 \pm 7.77$ & $78.8 \pm 6.58$ & $77.8 \pm 9.30$ & 0.535 \\
\hline \multirow{2}{*}{$\begin{array}{l}\text { The state of } \\
\text { seeing } \\
\text { children }\end{array}$} & Yes & $80.0 \pm 13.24$ & $80.4 \pm 9.66$ & $75.5 \pm 14.14$ & 0.238 \\
\hline & No & $78.9 \pm 12.90$ & $75.3 \pm 12.37$ & $78.1 \pm 13.72$ & 0.922 \\
\hline \multirow[t]{2}{*}{$\begin{array}{l}\text { Chronic } \\
\text { Diseases }\end{array}$} & $\begin{array}{l}\text { Two and } \\
\text { more }\end{array}$ & $71.4 \pm 10.49 *$ & $74.4 \pm 10.49$ & $73.5 \pm 10.63$ & 0.636 \\
\hline & No & 83.0 $\pm 9.52 *$ & $79.1 \pm 14.23$ & $79.9 \pm 13.49$ & 0.027 \\
\hline \multirow[t]{2}{*}{ DM } & Yes & $79.2 \pm 10.43$ & - & $75.3 \pm 11.48$ & 0.578 \\
\hline & No & $80.7 \pm 12.69$ & $78.0 \pm 7.28$ & $78.6 \pm 13.57$ & 0.878 \\
\hline \multirow[t]{2}{*}{ CRF } & Yes & $78.2 \pm 2.12$ & $78.5 \pm 2.12$ & $75.3 \pm 8.50$ & 0.663 \\
\hline & No & $80.1 \pm 11.24$ & $79.1 \pm 11.24$ & $78.2 \pm 14.10$ & 0.354 \\
\hline \multirow[t]{2}{*}{ HT } & Yes & $76.6 \pm 23.15$ & $65.8 \pm 9.30$ & $70.8 \pm 12.63$ & 0.580 \\
\hline & \begin{tabular}{|l|l} 
No \\
\end{tabular} & $82.4 \pm 28.59$ & $78.5 \pm 11.65$ & $79.8 \pm 14.34$ & 0.490 \\
\hline \multirow[t]{2}{*}{ CORP } & Yes & $79.7 \pm 12.85$ & $78.2 \pm 10.99$ & $76.8 \pm 11.43$ & 0.181 \\
\hline & No & $80.7 \pm 10.48$ & $77.0 \pm 10.81$ & $78.5 \pm 12.60$ & 0.665 \\
\hline \multirow{2}{*}{$\begin{array}{l}\text { Psychiatric } \\
\text { Illness }\end{array}$} & Yes & $69.7 \pm 10.64$ & $77.4 \pm 9.50$ & $73.6 \pm 10.88$ & 0.731 \\
\hline & No & 81.8 $\pm 12.85 *$ & $83.3 \pm 12.85$ & $79.0 \pm 14.85$ & 0.033 \\
\hline
\end{tabular}

*:p $<0.05 ;{ }^{* *}: \mathrm{p}<0.001 ;$ ANOVA test; 